\title{
PHYTOCHEMICAL STUDIES ON ANISE (PIMPINELLA ANISUM L.) PLANT UNDER USING CHEMICAL FERTILIZATION, BIOFERTILIZER AND THIDIAZURON TREATMENTS
}

\author{
BY \\ M. K. Khalil ${ }^{1}$, G. M. Ghazal ${ }^{2}$, A. Mahmoud ${ }^{1}$, D. A. Sallam ${ }^{2}$ \\ FROM \\ ${ }^{1}$ Plant Physiology section, Agric. Bot. Dept. Faculty of Agriculture, Cairo University, \\ Giza, Egypt. \\ ${ }^{2}$ Department of medicinal plant and natural products, National Organization for Drug \\ Control and Research, Giza, Egypt.
}

\begin{abstract}
A field experiment was conducted during two successive seasons of 2012/2013 and 2013/2014 at Phytochemistry Department and Farm of Applied Research Center of Medicinal Plants (ARCMP) affiliated to the National Organization for Drug Control And Research (NODCAR). Present work aimed to study the effect of inoculation Pimpinella anisum L. seeds with arbuscular mycorrhizal fungi (my) and/or microbein (mi) and/or foliar spray plants with thidiazuran (TDZ) combine with chemical fertilizer at half or full dose of NPK on the volume of the volatile oil of anise seeds, physiochemical investigation (Specific gravity of each essential oil and Refractive index of each essential oil), Compositional analysis by GLC of each essential oil percentage (linalol, estragole, alpha-terpenol, cis-anethole, trans- anethol and anisaldhyde), total phenolic content and total flavonoid content of dry seeds. The results showed that inoculation anise (Pimpinella anisum L.) seeds with mixture of mycorrhizal and microbein at full dose of NPK gave the highest yield of the volatile oil of anise seeds , total phenolic content and total flavonoid content of dry seeds. While treated plants with biofertilizer (mycorrhizal and/or microbein) /or sprayed plants with TDZ combine biofertilizer at half or full dose of NPK didn't have any significant effect on physiochemical investigation and compositional analysis of volatile oil by GLC as compared to the control.
\end{abstract}

\section{Introduction}

Anise (Pimpinella anisum L.), a plant belonging to the Umbelliferae family, is one of the oldest medicinal plants. It is an annual grassy herb, white flowers, and small green to yellow seeds, which grows in the Eastern Mediterranean Region, West Asia, the Middle East, Mexico, Egypt, and Spain (Salehi, 2010]. Study of essential oil of Pimpinella anisum L. fruits by GC and GC-MS showed the presence of trans-anethole (93.9\%) and estragole (2.4\%), other compounds that were found with concentration higher than $0.06 \%$ were (E)-methyleugenol, $\alpha$-cuparene, $\alpha$-himachalene, $\beta$-bisabolene, p-anisaldehyde, and cis-anethole (Özcan and Chalchat 2006). Pimpinella anisum had 
several therapeutic effects such as neurologic, digestive, gynecologic and respiration disorders. In addition, it was demonstrated that the Anise showed ovicidal activity against stored-product insects [Tunc, 2000]. In addition, Pimpinella anisum displayed another biological activity in the Central Nervous System (CNS) field. Indeed, the extract oil of this plant has been reported to delay the onset of picrotoxin-induced seizures in mice and anethole possesses muscle relaxant effect [Abdul-Ghani, 1987].

The term biofertilizer or called 'microbial inoculants' can be generally defined as a preparation containing live or latent cells of efficient strains of nitrogen fixing, phosphate solubilizing or cellulytic microorganisms used for application of seed, soil or composting areas with the objective of increasing the numbers of such microorganisms and accelerate certain microbial process to augment the extent of the availability of nutrients in a form which can assimilated by plant (Board, 2004). In large sense, the term may be used to include all organic resources (manure) for plant growth which are rendered in an available form for plant absorption through microorganisms or plant associations or interactions ( Board, 2004).

The utilization of microbial products has several advantages over conventional chemicals for agricultural purposes: (1) microbial products are considered safer than many of the chemicals now in use; (2) neither toxic substances nor microbes themselves will be accumulated in the food chain; (3) self-replication of microbes circumvents the need for repeated application; (4) target organisms seldom develop resistance as is the case when chemical agents are used to eliminate the pests harmful to plant growth; and (5) properly developed biocontrol agents are not considered harmful to ecological processes or the environment (Wua et al, 2004).

Thidiazuron (N-phenyl- $N^{\prime}-1,2,3,-$ thiadiazol-5-ylurea), is a synthetic diphenylurea (DPU) type cytokinin that is thought to encourage the synthesis and /or accumulation of purine type cytokinins (Thomas and Katterman, 1986). Si AiChun et al. (2005) used the solution made of $30 \mathrm{ml}$ of $0.1 \%$ Yiguoling (produced in China, the main ingredient is TDZ [thidiazuron]) was sprayed once at the beginning of flowering and once again at full bloom of apple tree. Yiguoling greatly increased the yield and fruit quality. The yield was increased by 4.6-4.8 t/ha, and the fruit soluble solids content was increased by $1.8-3.3 \%$. The fruit coloration was also much better than that of the control. The effect of treatment milk thistle with foliar fertilizers and thidiazuron (Dropp Reg.) studied by (Geneva et al., 2008), and investigated that, The highest content of silymarin was found in plants treated with Dropp Reg.

The aim of the present work was to study the effect of my, mi and TDZ combined with half or full dose of NPK on active constituents of anise plant. 


\section{MATERIALS AND METHODS}

\section{Plant material}

Seeds of Pimpinella anisum L. obtained from Harraz market for Seeds and Pesticides (Bab El Khalk square, Cairo, Egypt).

microorganisms material:-

1. Mycorrhizal (contains Gloums spp., Gigaspora spp. and Acaulospora spp. V 1:1:1) obtained from Soil, Water and Environment Research Institute.

2. Mycrobein (biofertilizer containing $\mathrm{N}$-fixing [such as Azotobacter and Azospirillum] and P-dissolving bacteria [Such as Pseudomonas and Bacillus megatheium] produced and distributed commercially by the General Organization for Agriculture Equalization Fund. Ministry of Agriculture, Egypt.

Mycorrhizal and microbein coated the seed of anise pre-planting by mixing with a fine mist of $10 \%$ sugar solution and mixing seed with the microbein and Mycorrhizal spores.

\section{Thiduazoran growth regulators} TDZ).

Obtained from commercially compound named Prop 50 ${ }^{\circledR}$ WP (containing 50\%

Plants were sprayed during vegetative growth (at 45 and 60 days after sowing) with $10 \mathrm{ml}$ of a solution containing ( $5 \mathrm{mg} / \mathrm{l} \mathrm{TDZ}$ dissolving in water containing $0.01 \%$ tween 20\%) using a hand atomizer. Weighing the plants before and after spraying showed that approximately 5 to $7 \mathrm{ml}$ of the solution adhered to each plant. Control plants were sprayed with water containing $0.01 \%$ tween $20 \%$ but without TDZ.

\section{Soil used}

The soil used in the present work are collected the from farm of Applied Research Center soil of Medicinal Plants (ARCMP) related to The National Orgnization for Drug Control And Research (NODCAR) and initially analyzed for chemical and physical characters according to Black et al. (1965). These characters are presented in Table (1). 
Table (1): Chemical and physical characteristics of the experimental soil

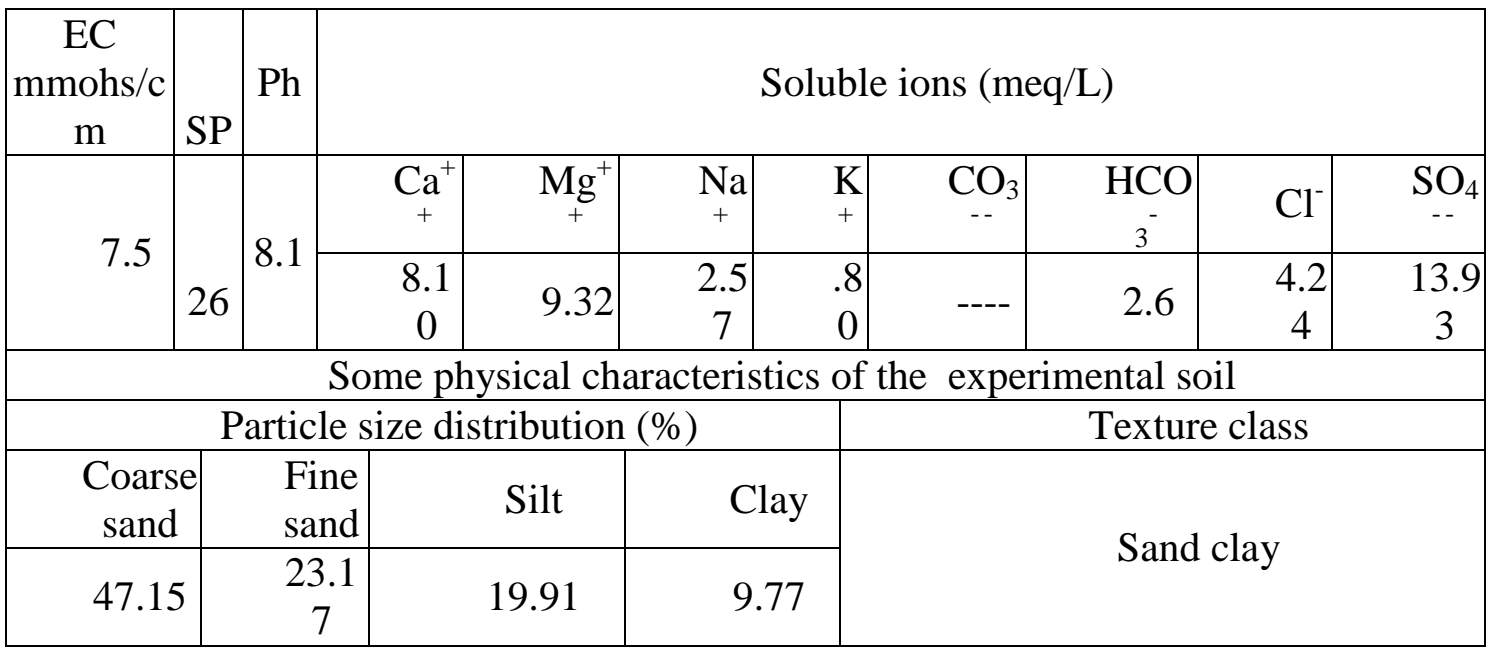

\section{Experimental design and layout}

The experiment was laid out in randomized block design (RBD) $(6 \times 7 \mathrm{~m})$ with 3 replications; each block was prepared to contain 10 rows, seeds were sowed at a plant density of 5 plants $\mathrm{m}^{2}$. Randomization of the treatments was done with the help of random number table as advocated by Fisher, 1950. The treatments were:-

1) Untreated plants with chemical and bio-fertilizer (zero)

2) Recommended dose of chemical fertilizer (Control).

3) Recommended dose of chemical fertilizer + mycorrhizal

4) Recommended dose of chemical fertilizer + microbein

5) Recommended dose of chemical fertilizer + TDZ

6) Recommended dose of chemical fertilizer + mycorrhizal + microbein

7) Recommended dose of chemical fertilizer + mycorrhizal + TDZ

8) Recommended doses of chemical fertilizer + microbein + TDZ

9) Half recommended dose of chemical fertilizer .

10) Half recommended dose of chemical fertilizer + mycorrhizal

11) Half recommended dose of chemical fertilizer + microbein

12) Half recommended dose of chemical fertilizer + TDZ

13) Half recommended dose of chemical fertilizer + mycorrhizal + microbein

14) Half recommended dose of chemical fertilizer + mycorrhizal + TDZ

15) Half recommended doses of chemical fertilizer + microbein + TDZ

Recommended dose of chemical fertilizer were $200 \mathrm{~kg} /$ Fadden superphosphate $\left(12.5 \% \quad \mathrm{P}_{2} \mathrm{O}_{5}\right)$ added before planting, while the plants were fertilizer with 200 $\mathrm{Kg} /$ Fadden ammonium sulphate $(20.6 \% \mathrm{~N})$ and $50 \mathrm{Kg} / \mathrm{Fadden}$ potassium sulphate $\left(50 \% \mathrm{KO}_{2}\right)$ after 30 and 45 days from planting at two stage.

Seeds of anise were planted in October and harvested in May. 


\section{Extraction of essential oil}

The essential oil from the seeds of Pimpinella anisum L. was extracted by steam distillation method as described previously by (Mazari et al., 2010). Steam containing volatile oil stored at a low temperature until further analysis.

\section{The yield of the volatile oil}

Volatile oil in plants are determined by distilling the dry seeds with water, collecting the distillate in a graduated tube in which the aqueous portion of the distillate is automatically separated and returned to the distilling flask, measuring the volume of the oil in the distillate and calculating the percentage as volume to weight (v/w).

\section{Physiochemical investigation}

a) Specific gravity

Specific gravity of the essential oil was measured with a specific gravity bottle of $10 \mathrm{ml}$ capacity. Following the acetone cleanse, the acetone fumes were removed by air blasts, and the specific gravity bottle was dried thoroughly. The specific gravity bottle was then filled with reference liquid, and its weight was measured on an analytical balance. Then, the specific gravity bottle was emptied, dried, filled with essential oil, and the weight was recorded accurately.

b) Refractive index

The refractive index of each essential oil was determined with use of a Refractometer. The prism was opened washed with acetone and dried. A few drops of the essential oil were placed on the prism. The field of vision was divided into light and dark portions. The refractive index of essential oil was noted on the display

c) Compositional analysis by GLC

Gas chromatographic analysis of absolute oil of Pimpinella anisum L. was carried out using HP Gas Chromatograph, Model G1530A. The other analysis conditions were as, column Zebron $(30 \mathrm{~m} \times 0.25 \mathrm{~mm} \times 0.10$ film thick $)$, initial oven temperature $60^{\circ} \mathrm{C}$, final oven temperature $300^{\circ} \mathrm{C}$. The initial Injector and detector temperature were 225 and $275^{\circ} \mathrm{C}$, respectively. Moisture free pure nitrogen at a flow rate of $10 \mathrm{ml} /$ minute was used as carrier gas. The constituents of essential oil of Pimpinella anisum L. were identified by comparing their relative and absolute retention times with those of authentic standards. The Essential oil composition was reported as a relative percentage of the peak area. 


\section{Determination of total phenolic and total flavonoid assay}

\section{Sample preparation}

A ground dried seeds of one gram was weighted and phenolic and flavonoid compounds were extracted with $50 \mathrm{ml} 80 \%$ aqueous methanol on an ultrasonic water bath for 20 minutes. An aliquot $(2 \mathrm{ml})$ of the extracts was ultra centrifuge for 5 minutes at $14000 \mathrm{rpm}$ ( Marinova, et al., 2005) .

\section{Determination of total phenolic}

The total phenolic content of dry seeds was determined by using the FolinCiocalteau assay. An aliquot $(1 \mathrm{ml})$ of extracts or standard solution of gallic acid (20, 40, 60, 80 and $100 \mathrm{mg} / \mathrm{l}$ ) was added to $25 \mathrm{~mL}$ volumetric flask, containing $9 \mathrm{~mL}$ of distilled deionized water (dd water). Reagent blank using dd water was prepared. One milliliter of Folin- Ciocalteu's phenol reagent was added to the mixture and shaken. After 5 minutes, $10 \mathrm{~mL}$ of $7 \%$ Sodium carbonate solution was added to the mixture. The solution was diluted to volume $(25 \mathrm{~mL})$ with dd water and mixed. After incubation for 90 minutes at room temperature, the absorbance against prepared reagent blank was determined at $750 \mathrm{~nm}$ with Spectrophotometer. Data of total phenolic contents of seeds are expressed as milligrams of gallic acid equivalents (GAE) per gram dry weight (mg GAE/g dw.). All samples were analyzed in triplicate ( Marinova, et al., 2005) .

\section{Determination of total flavonoid assay:}

Total flavonoid content was measured by aluminum chloride colorimetric assay. An aliquot $(1 \mathrm{ml})$ of extracts or standard solution of (+)-catechin $(20,40,60,80$ and 100 $\mathrm{mg} / \mathrm{l}$ ) was added to $10 \mathrm{~mL}$ volumetric flask, containing $4 \mathrm{~mL}$ of deionizer water. To the flask $0.3 \mathrm{~mL} 5 \%$ sodium nitrite was added. After 5 minutes, $0.3 \mathrm{~mL} 10 \%$ aluminium chloride was added. After sixth minutes, $2 \mathrm{~mL} 1 \mathrm{M}$ sodium hydroxide was added and the total volume was made up to $10 \mathrm{~mL}$ with dd water. The solution was mixed well and the absorbance was measured against prepared reagent blank at $510 \mathrm{~nm}$ with Spectrophotometer. Data of total flavonoid contents of dry seeds are expressed as milligrams of (+)- catechin equivalents (CE) per gram dry weight (mg CE/g dw). All samples were analyzed in triplicate ( Marinova, et al., 2005) .

\section{Statistical analysis}

Data recorded on vegetative growth and chemical compositions were statistically analyzed, and separation of means was performed using the least significant difference (L.S.D.) test at the 5\% level, as described by (Snedecor and Cochran, 1967).

\section{RESULTS AND DISCUSSIONS}

a) Effect of chemical fertilization, bio-fertilizer and TDZ on the yield of the volatile oil of Pimpinella anisum L. plant 
Data concerning the effect of inoculation anise (Pimpinella anisum L.) seeds with biofertilizer (mycorrhizal and/or microbein) /or sprayed plants with TDZ combined with biofertilizer at half or full dose of NPK on the volume of the volatile oil $(\mathrm{ml} / \mathrm{kg}$ dry seeds) are presented in Table (2).

Data showed that treated anise (Pimpinella anisum L.) with biofertilizer and /or TDZ at full recommended dose of NPK significantly increased yield of the volatile oil ( $\mathrm{ml} / \mathrm{kg}$ dry seeds) as compared to treated anise (Pimpinella anisum L.) plants with biofertilizer and /or TDZ at half recommended dose of NPK.

Also the data showed that inoculation anise (Pimpinella anisum L.) seeds with mixture of mycorrhizal and microbein at full dose of NPK gave the highest yield of the volatile oil (ml/kg dry seeds) were (35.70 and 38.10) recorded in the first and second seasons respectively. On the other hand, the lowest yield of the volatile oil $(\mathrm{ml} / \mathrm{kg}$ dry seeds) obtained with zero treatment in two seasons at those values were (12.15 and $13.30 \mathrm{ml} / \mathrm{kg}$ dry seeds) on anise (Pimpinella anisum L.) plant respectively.

These results agree with the finding of Harb et al., (2011) on Nigella sativa L. plants they indicated that G.macrocarpus fungus alone or combined with nitrobein at full NPK fertilizer treatment led to increase the essential oil content in seeds. In this respect, Hellal et al., (2011) showed that the highest values of (Anethum graveolens L.) oil yield content was recorded by the treatment of bio-fertilizer plus $2 / 3$ of recommended dose of nitrogen fertilizer. In this connection, El-Gendy et al. (2013) they showed that on Cymbopogon Citratus plants the interaction treatment between of $\mathrm{N}$ and biofertilizers led to significant increment for yield of essential oil compared to control during both seasons.

Similar results were recorded by Ghilavizadeh et al. (2013) showed that biofertilizer (mixture of Azotobacter chroococcum and Azospirillum lipoferum) had significant effects on studied traits of Ajowan (Carum copticum). The highest essential oil content and essential oil yield were obtained by using the biofertilizer twice (inoculated seeds + spray on the plant base at stem elongation stage). In this respect, Roshanpour et al . (2014) showed that the highest essential oil content of basil (Ocimum basilicum L.) and the minimum caryophyllene oxide in essential oil were obtained after applying each three biofertilizers (Azotobacter chroococcum (A) + Azospirillum lipoferum $(\mathrm{B})+$ Bacillus circulans $(\mathrm{C})$ ). The maximum geranial in essential oil and the minimum caryophyllene in essential oil were obtained by using two biofertilizers $(\mathrm{A}+\mathrm{C})$. Also, the highest methyl chavicol in essential oil was obtained after applying two biofertilizers $(\mathrm{B}+\mathrm{C})$.

b) Effect of chemical fertilization, bio-fertilizer and TDZ on Physiochemical investigation (Specific gravity and Refractive index) and Compositional analysis of volatile oil by GLC of Pimpinella anisum L. plant

The data in Tables (3-10) showed that treated biofertilizer (mycorrhizal and/or microbein) /or sprayed plants with TDZ combined with biofertilizer at half or full dose of NPK didn't have any significant effect on physiochemical investigation (Specific gravity and Refractive index) and compositional analysis of volatile oil percentage by 
GLC (linalol, estragole, alpha-terpenol, cis-anethole, trans- anethol and anisaldhyde) as compared to the control.

c) Effect of chemical fertilization, bio-fertilizer and TDZ on total phenols of Pimpinella anisum L. seed

For the effect of chemical, biofertilizer and TDZ on total phenolic content (mg/g seeds) in dry seeds of anise (Pimpinella anisum L.) plant, the obtained results in Table (11) indicated that inoculation anise (Pimpinella anisum L.) seeds with mixture of mycorrhizal and microbein at full recommended dose of NPK led to significantly increased of total phenolic ( $\mathrm{mg} / \mathrm{g}$ seeds) content in dry seeds as compared to control.

Also the data cleared that the highest values of total phenolic content $(\mathrm{mg} / \mathrm{g}$ seeds) in dry seeds of anise (Pimpinella anisum L.) were $(5.75$ and $6.38 \mathrm{mg} / \mathrm{g}$ ) obtained by inoculation anise (Pimpinella anisum L.) seeds with mixture of mycorrhizal and microbein at full dose of NPK in the first and second seasons respectively. On the other hand, the lower values were $(3.85$ and $4.29 \mathrm{mg} / \mathrm{g}$ ) obtained by zero treatment in the first and second seasons, respectively.

Similar results were recorded by Aseri et al. (2008) they reported that, Inoculation Pomegranate (Punica granatum L.) with Azotobacter chroococcum , A. brasilense, Glomus mosseae and G. fasciculatum, had resulted in a significantly higher accumulation of total phenols in 4 months old inoculated plants.

El-Gendy et al. (2013) they reported that treated lemongrass (Cymbopogon citrates) with biofertilizers (nitrobein \& rhizobacteria and microbein) with urea led to significant increment of polyphenol. In this connection, Seifi et al. (2014) they mentioned that inoculation olive with using two arbuscular mycorrhizal fungi species including Glomus mosseae and G. interaradices led to significantly increased leaf total phenols.

Effect of chemical fertilization, bio-fertilizer and TDZ on total flavonoid of Pimpinella anisum L. seed

Data listed in Table (12) showed that the total flavonoid content (mg/g) was increased in seeds resulting from inoculation anise (Pimpinella anisum L.) seeds with biofertilizer and/or foliar plants with TDZ at full recommended dose of NPK as compared to control in all treatments.

Also the data showed that the highest values of total flavonoid content $(\mathrm{mg} / \mathrm{g}$ seeds) in dry seeds of anise (Pimpinella anisum L.) were $(2.21$ and $2.45 \mathrm{mg} / \mathrm{g}$ ) obtained by inoculation anise (Pimpinella anisum L.) seeds with mixture of mycorrhizal and microbein at full dose of NPK in the first and second seasons respectively. On the other hand, the lower values were $(1.0$ and $1.03 \mathrm{mg} / \mathrm{g})$ obtained by zero treatment in the first and second seasons, respectively.

These results were in harmony with the finding by El-Gendy et al. (2013) they showed that treated lemongrass (Cymbopogon citrates) with biofertilizer (nitrobein \& 
rhizobacteria and microbein) with urea led to significant effect of flavonoid content in both seasons. This agreed with the result obtained by (Faramawy., 2014) reported that inoculation Prosopis chilensis with Bradyhizobium japonicum, Azotobacter chroococcum, Bacillus megatherium and VA mycorrhizal led to significantly increased total flavonoids.

Table 2. Effect of chemical fertilization, biofertilizer and TDZ on mean yield of volatile oil (ml/Kg dry seeds) of anise plant during 2012/2013 and 2013/2014 seasons.

\begin{tabular}{|c|c|c|c|}
\hline \multirow{2}{*}{ Treatment } & \multicolumn{3}{|c|}{ Growing season } \\
\hline & $2012-2013$ & 2013-2014 & Mean \\
\hline Zero & 12.15 & 13.3 & 12.73 \\
\hline full dose & 26.00 & 28.62 & 27.31 \\
\hline full + my & 30.22 & 33.87 & 32.05 \\
\hline full + mi & 29.11 & 32.00 & 30.56 \\
\hline full + TDZ & 27.52 & 30.55 & 29.04 \\
\hline full $+\mathrm{my}+\mathrm{mi}$ & 35.70 & 38.10 & 36.90 \\
\hline full + my + TDZ & 32.50 & 35.00 & 33.75 \\
\hline full + mi + TDZ & 31.15 & 34.25 & 32.70 \\
\hline half dose & 15.00 & 16.75 & 15.88 \\
\hline half + my & 17.25 & 18.00 & 17.63 \\
\hline half $+\mathrm{mi}$ & 16.50 & 17.57 & 17.04 \\
\hline half + TDZ & 15.82 & 17.00 & 16.41 \\
\hline half $+m y+m i$ & 20.1 & 21.37 & 20.74 \\
\hline half + my + TDZ & 18.45 & 20.00 & 19.23 \\
\hline half + mi + TDZ & 17.77 & 18.5 & 18.14 \\
\hline Mean & 23.02 & 24.99 & \\
\hline L.S.D.0.05 & 4.45 & 5.07 & \\
\hline
\end{tabular}


Table 3. Effect of chemical fertilization, biofertilizer and TDZ on mean specific gravity of volatile oil in dry seeds of anise plant during 2012/2013 and 2013/2014 seasons.

\begin{tabular}{llll}
\hline \multirow{2}{*}{ Treatment } & \multicolumn{2}{l}{ Growing season } & \\
\cline { 2 - 4 } & $2012-2013$ & $2013-2014$ & Mean \\
\hline Zero & 0.984 & 0.992 & 0.988 \\
full dose & 0.993 & 0.984 & 0.989 \\
full + my & 0.975 & 1.000 & 0.988 \\
full + mi & 0.988 & 0.979 & 0.984 \\
full + TDZ & 0.981 & 0.990 & 0.986 \\
full + my + mi & 0.990 & 0.995 & 0.993 \\
full + my + TDZ & 0.979 & 0.980 & 0.980 \\
full + mi + TDZ & 1.000 & 0.985 & 0.993 \\
half dose & 0.991 & 0.993 & 0.992 \\
half + my & 1.000 & 0.978 & 0.989 \\
half + mi & 0.980 & 0.980 & 0.980 \\
half + TDZ & 0.990 & 0.970 & 0.980 \\
half + my + mi & 0.993 & 0.995 & 0.994 \\
half + my + TDZ & 0.989 & 0.997 & 0.993 \\
half + mi + TDZ & 0.978 & 0.985 & 0.982 \\
Mean & 0.990 & 0.990 & \\
\hline L.S. D .05 & NS & NS &
\end{tabular}

Table 4. Effect of chemical fertilization, biofertilizer and TDZ on mean refractive index of volatile oil in dry seeds of anise plant during 2012/2013 and 2013/2014 seasons.

\begin{tabular}{llll}
\hline \multirow{2}{*}{ Treatment } & \multicolumn{2}{l}{ Growing season } & \\
\cline { 2 - 4 } & $2012-2013$ & $2013-2014$ & Mean \\
\hline Zero & 1.553 & 1.560 & 1.557 \\
full dose & 1.562 & 1.555 & 1.559 \\
full + my & 1.557 & 1.557 & 1.557 \\
full + mi & 1.554 & 1.560 & 1.557 \\
full + TDZ & 1.560 & 1.552 & 1.556 \\
full + my + mi & 1.560 & 1.554 & 1.557 \\
full + my + TDZ & 1.561 & 1.558 & 1.560
\end{tabular}




$\begin{array}{llll}\text { full + mi + TDZ } & 1.557 & 1.561 & 1.559 \\ \text { half dose } & 1.558 & 1.557 & 1.558 \\ \text { half + my } & 1.553 & 1.560 & 1.557 \\ \text { half + mi } & 1.555 & 1.558 & 1.557 \\ \text { half + TDZ } & 1.562 & 1.553 & 1.558 \\ \text { half + my + mi } & 1.564 & 1.560 & 1.562 \\ \text { half + my + TDZ } & 1.560 & 1.559 & 1.560 \\ \text { half + mi + TDZ } & 1.557 & 1.580 & 1.569 \\ \text { Mean } & 1.560 & 1.560 & \end{array}$

L.S.D.0.05

NS

NS

Table 5. Effect of chemical fertilization ,biofertilizer and TDZ on mean linalol\% of volatile oil in dry seeds of anise plant during 2012/2013 and 2013/2014 seasons.

\begin{tabular}{llll}
\hline \multirow{2}{*}{ Treatment } & \multicolumn{2}{l}{ Growing season } & \\
\cline { 2 - 4 } & $2012-2013$ & $2013-2014$ & Mean \\
\hline Zero & 0.03 & 0.04 & 0.04 \\
full dose & 0.04 & 0.02 & 0.03 \\
full + my & 0.03 & 0.03 & 0.03 \\
full + mi & 0.02 & 0.03 & 0.03 \\
full + TDZ & 0.04 & 0.05 & 0.05 \\
full + my + mi & 0.05 & 0.02 & 0.04 \\
full + my + TDZ & 0.03 & 0.03 & 0.03 \\
full + mi + TDZ & 0.03 & 0.03 & 0.03 \\
half dose & 0.03 & 0.04 & 0.04 \\
half + my & 0.02 & 0.04 & 0.03 \\
half + mi & 0.02 & 0.03 & 0.03 \\
half + TDZ & 0.03 & 0.03 & 0.03 \\
half + my + mi & 0.03 & 0.04 & 0.04 \\
half + my + TDZ & 0.04 & 0.03 & 0.04 \\
half + mi + TDZ & 0.03 & 0.02 & 0.03 \\
Mean & 0.03 & 0.03 & \\
\hline
\end{tabular}

L.S.D.0.05

NS

NS 
Table 6. Effect of chemical fertilization,biofertilizer and TDZ on mean estragole $\%$ of volatile oil in dry seeds of anise plant during 2012/2013 and 2013/2014 seasons.

\begin{tabular}{llll}
\hline \multirow{2}{*}{ Treatment } & \multicolumn{2}{l}{ Growing season } & \\
\cline { 2 - 4 } & $2012-2013$ & $2013-2014$ & Mean \\
\hline Zero & 0.58 & 0.76 & 0.67 \\
full dose & 0.70 & 0.70 & 0.70 \\
full + my & 0.61 & 0.76 & 0.69 \\
full + mi & 0.63 & 0.74 & 0.69 \\
full + TDZ & 0.67 & 0.72 & 0.70 \\
full + my + mi & 0.66 & 0.70 & 0.68 \\
full + my + TDZ & 0.62 & 0.68 & 0.65 \\
full + mi + TDZ & 0.85 & 0.64 & 0.75 \\
half dose & 0.58 & 0.70 & 0.64 \\
half + my & 0.65 & 0.69 & 0.67 \\
half + mi & 0.76 & 0.66 & 0.71 \\
half + TDZ & 0.85 & 0.53 & 0.69 \\
half + my + mi & 0.75 & 0.64 & 0.70 \\
half + my + TDZ & 0.65 & 0.80 & 0.73 \\
half + mi + TDZ & 0.65 & 0.78 & 0.72 \\
Mean & 0.68 & 0.70 & \\
\hline L.S.D.0.05 & $\mathrm{NS}$ & $\mathrm{NS}$ &
\end{tabular}

Table 7. Effect of chemical fertilization, biofertilizer and TDZ on mean alpha-terpenol $\%$ of volatile oil in dry seeds of anise plant during 2012/2013 and 2013/2014 seasons.

\begin{tabular}{llll}
\hline \multirow{2}{*}{ Treatment } & \multicolumn{2}{l}{ Growing season } & \\
\cline { 2 - 4 } & $2012-2013$ & $2013-2014$ & Mean \\
\hline Zero & 0.04 & 0.05 & 0.05 \\
full dose & 0.06 & 0.04 & 0.05 \\
full + my & 0.05 & 0.06 & 0.06 \\
full + mi & 0.05 & 0.05 & 0.05 \\
full + TDZ & 0.07 & 0.04 & 0.06 \\
full + my + mi & 0.06 & 0.05 & 0.06 \\
full + my + TDZ & 0.06 & 0.04 & 0.05 \\
full + mi + TDZ & 0.05 & 0.05 & 0.05 \\
half dose & 0.04 & 0.07 & 0.06 \\
half + my & 0.05 & 0.05 & 0.05 \\
half + mi & 0.05 & 0.04 & 0.05 \\
half + TDZ & 0.04 & 0.05 & 0.05 \\
half + my + mi & 0.04 & 0.06 & 0.05 \\
half + my + TDZ & 0.05 & 0.06 & 0.06 \\
half + mi + TDZ & 0.04 & 0.05 & 0.05
\end{tabular}




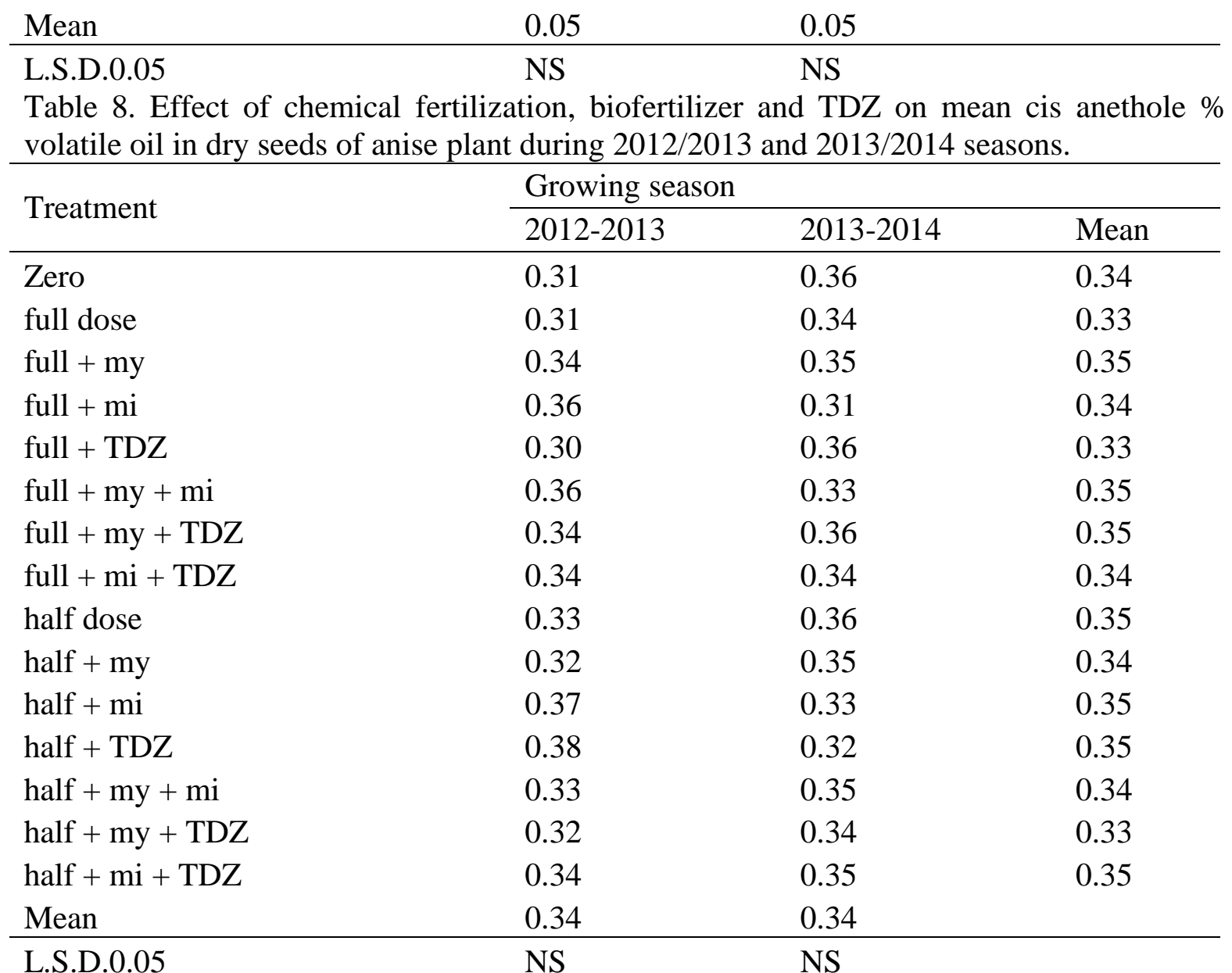


Table 9. Effect of chemical, biofertilizer and TDZ on mean trans anethole \% of volatile oil in dry seeds of anise plant during 2012/2013 and 2013/2014 seasons.

\begin{tabular}{|c|c|c|c|}
\hline \multirow{2}{*}{ Treatment } & \multicolumn{3}{|c|}{ Growing season } \\
\hline & $2012-2013$ & $2013-2014$ & Mean \\
\hline Zero & 90.73 & 90.00 & 90.37 \\
\hline full dose & 91.43 & 91.78 & 91.61 \\
\hline full + my & 89.43 & 90.33 & 89.88 \\
\hline full $+\mathrm{mi}$ & 90.91 & 90.72 & 90.82 \\
\hline full + TDZ & 90.88 & 90.35 & 90.62 \\
\hline full + my + mi & 90.02 & 90.00 & 90.01 \\
\hline full + my + TDZ & 89.18 & 91.25 & 90.22 \\
\hline full + mi + TDZ & 90.28 & 91.80 & 91.04 \\
\hline half dose & 91.94 & 91.42 & 91.68 \\
\hline half + my & 89.34 & 90.35 & 89.85 \\
\hline half + mi & 90.33 & 90.80 & 90.57 \\
\hline half + TDZ & 91.13 & 89.99 & 90.56 \\
\hline half + my + mi & 91.76 & 90.33 & 91.05 \\
\hline half + my + TDZ & 91.03 & 91.13 & 91.08 \\
\hline half $+\mathrm{mi}+\mathrm{TDZ}$ & 91.87 & 90.00 & 90.94 \\
\hline Mean & 90.68 & 90.68 & \\
\hline L.S.D.0.05 & NS & NS & \\
\hline
\end{tabular}

Table 10. Effect of chemical fertilization, biofertilizer and TDZ on mean anisaldhyde $\%$ of volatile oil in dry seeds of anise plant during 2012/2013 and 2013/2014 seasons.

\begin{tabular}{llll}
\hline \multirow{2}{*}{ Treatment } & \multicolumn{2}{l}{ Growing season } & \\
\cline { 2 - 4 } & $2012-2013$ & $2013-2014$ & Mean \\
\hline Zero & 0.41 & 0.25 & 0.33 \\
full dose & 0.23 & 0.39 & 0.31 \\
full + my & 0.40 & 0.29 & 0.35 \\
full + mi & 0.37 & 0.31 & 0.34 \\
full + TDZ & 0.38 & 0.25 & 0.32 \\
full + my + mi & 0.41 & 0.28 & 0.35 \\
full + my + TDZ & 0.40 & 0.30 & 0.35 \\
full + mi + TDZ & 0.43 & 0.25 & 0.34 \\
half dose & 0.25 & 0.37 & 0.31 \\
half + my & 0.35 & 0.33 & 0.34 \\
half + mi & 0.36 & 0.32 & 0.34 \\
half + TDZ & 0.33 & 0.25 & 0.29 \\
half + my + mi & 0.31 & 0.34 & 0.33 \\
half + my + TDZ & 0.34 & 0.31 & 0.33 \\
half + mi + TDZ & 0.33 & 0.31 & 0.32 \\
Mean & 0.35 & 0.30 & \\
\hline L.S.D.0.05 & NS & NS &
\end{tabular}


Table 11. Effect of chemical fertilization, biofertilizer and TDZ on mean total phenolic content (mg/g) in dry seeds of anise plant during 2012/2013 and 2013/2014 seasons.

\begin{tabular}{llll}
\hline \multirow{2}{*}{ Treatment } & \multicolumn{2}{l}{ Growing season } & \\
\cline { 2 - 4 } & $2012-2013$ & $2013-2014$ & Mean \\
\hline Zero & 3.85 & 4.29 & 4.07 \\
full dose & 4.85 & 5.60 & 5.23 \\
full + my & 5.25 & 5.87 & 5.56 \\
full + mi & 5.16 & 5.80 & 5.48 \\
full + TDZ & 5.09 & 5.69 & 5.39 \\
full + my + mi & 5.75 & 6.38 & 6.07 \\
full + my + TDZ & 5.47 & 6.17 & 5.82 \\
full + mi + TDZ & 5.30 & 6.00 & 5.65 \\
half dose & 4.03 & 4.72 & 4.38 \\
half + my & 4.31 & 5.11 & 4.71 \\
half + mi & 4.21 & 5.00 & 4.61 \\
half + TDZ & 4.10 & 4.88 & 4.49 \\
half + my + mi & 4.60 & 5.38 & 4.99 \\
half + my + TDZ & 4.60 & 5.30 & 4.95 \\
half + mi + TDZ & 4.35 & 5.21 & 4.78 \\
Mean & 4.73 & 5.43 & \\
\hline L.S.D.0.05 & 0.42 & 0.46 &
\end{tabular}


Table 12. Effect of chemical fertilization, biofertilizer and TDZ on mean total flavonoides content (mg/g) in dry seeds of anise plant during 2012/2013 and 2013/2014 seasons.

\begin{tabular}{|c|c|c|c|}
\hline \multirow{2}{*}{ Treatment } & \multicolumn{3}{|c|}{ Growing season } \\
\hline & $2012-2013$ & 2013-2014 & Mean \\
\hline Zero & 1.00 & 1.03 & 1.02 \\
\hline full dose & 1.69 & 1.85 & 1.77 \\
\hline full + my & 2.07 & 2.15 & 2.11 \\
\hline full + mi & 2.05 & 2.09 & 2.07 \\
\hline full + TDZ & 1.80 & 2.00 & 1.90 \\
\hline full + my + mi & 2.21 & 2.45 & 2.33 \\
\hline full + my + TDZ & 2.18 & 2.30 & 2.24 \\
\hline full + mi + TDZ & 2.10 & 2.21 & 2.16 \\
\hline half dose & 1.10 & 1.10 & 1.10 \\
\hline half + my & 1.22 & 1.38 & 1.30 \\
\hline half + mi & 1.17 & 1.30 & 1.24 \\
\hline half + TDZ & 1.10 & 1.20 & 1.15 \\
\hline half + my + mi & 1.50 & 1.63 & 1.57 \\
\hline half + my + TDZ & 1.37 & 1.51 & 1.44 \\
\hline half $+\mathrm{mi}+\mathrm{TDZ}$ & 1.30 & 1.45 & 1.38 \\
\hline Mean & 1.59 & 1.71 & \\
\hline L.S.D.0.05 & 0.16 & 0.18 & \\
\hline
\end{tabular}

\section{REFERENCES}

Abdul-Ghani, A.S.; El-Lati, S.G.; Sacaan, A.I.and Suleiman, M.S.(1987). Anticonvulsant effects of some arab medicinal plants, International Journal of Crude Drug Research, 25, 39;

Aseri, G.K.; Jain, N., Panwar, J., Rao, A.V. and Meghwal, P.R. (2008) Biofertilizers improve plant growth, fruit yield, nutrition, metabolism and rhizosphere enzyme activities of Pomegranate (Punica granatum L.) in Indian Thar desert. Scientia Horticulturae 117: 130135.

Black, C. A.; Evans, D. D.; White, J. L.; Ensmiger, L. E. and Clark, F. E. (1965). Methods of soil analysis. Part 2. Agronomy. 9, ASA, Madison, WI, 1122pp.

Board, N.I.I.R. (2004). The Complete Technology Book On Bio-Fertilizer And Organic Farming. National Institute of Industrial Re.

EI Gendy A.G., Taghred A. Hegazy and S.M. EISayed, 2013.Effect of bio-fertilizers and/or urea on growth, yield, essential oil and chemical compositions of Cymbopogon Citratus plants.Journal of Applied Sciences Research, 9(1): 309-320. 
Faramawy, M. K. (2014). Response of Prosopis Chilensis to biofertilization under calcareous soil of RasSudr. 2 - Pod production. Annals of Agricultural Sciences Volume 59, Issue 2, December 2014, Pages 263-271.

Fisher, R.A. (1950). Statistical method for research workers, Oliver and Boyd, Edinburg, London.

Geneva, M.; Zehirov, G.; Stancheva, I.; Iliev, L. and Georgiev, G. (2008). Effect of soil fertilizer, foliar fertilizer and growth regulator application on milk thistle (Silybum marianum L.) development, seed yield, and silymarin content. Commun. Soil Sci Plant Anal., 39, 17-24.

Ghilavizadeh, A.; Darzi, M.T. and Hadi, M.H.S. (2013) Effects of biofertilizer and plant density on essential oil content and yield traits of ajowan (Carum copticum) Middle-East J. Sci. Res., 14 (11), pp. 1508-1512

Harb, E.M.Z.; Ghallab, A.M. and Soliman, S.H.D. (2011). Effect of mycorrhizae, azotobacter and organic manure on the growth, seed yield and oil content of Nigella sativa L. plants grown under two levels of chemical fertilizers, NPK. Bull. Fac. Agric. Cairo Univ., 62: 173-182.

Hellal, F.A.; Mahfouz, S.A. and Hassan, F.A.S. (2011). Partial substitution of mineral nitrogen fertilizer by bio- fertilizer on (Anethum graveolens L.) plant. Agriculture and Biol. J. North America. 2(4), 652- 660.

Marinova, D.; Ribarova, F. and Atanassova, M. (2005). Total phenolics and total flavonoids in Bulgaria fruits and vegetables. Journal of the University of Chemical Technology and Metallurgy, 40: 255-260. Ness AR; Powles JW (1997). Fruit and vegetables and cardiovascular.

Mazari, K. Bendimerad, N. Bekhechi, C. and Fernandez, X. (2010). Chemical composition and antimicrobial activity of essential oils isolated from Algerian Juniperus phoenicea L. and Cupressus sempervirens L. J Med Plants Res, 4:959-964.

Özcan, M. M. and Chalchat, J.C. (2006). Chemical composition and antifungal effect of anise (Pimpinella anisum L.) fruit oil at ripening stage. Annals of Microbiology. 56(4):353-358.

Roshanpour, N.; Darzi, M. T. and Hadi, M. H. S. (2014). Quantity and Quality of essential oil of basil (Ocimum basilicum L.) under biofertilizers application conditions. International journal of Advanced Biological and Biomedical Research Volume 2, Issue 6, 2014: 2134-2142. 
Seifi, E.; Teymoor, Y.; Alizadeh, M. and Fereydooni, H.(2014). Olive mycorrhization: Influences of genotype, mycorrhiza, and growing periods. Scientia Horticulturae. 11/2014; 180.

Salehi S. M. H. (2010). Medicinal Plants and Phytotherapy. Vol. 1. Tehran, Iran: Donyay Taghziah Press; 2010.

Si AiChun; Dong ZhengYuan; Tang MinShe; Xin XuanMin; Zhao Feng (2005). Experiment of spraying Yiguoling plant regulator for increasing apple production and fruit quality. [Chinese] China Fruits; (4):12-14.

Snedecor, G.W. and Cochran, W.G. (1967) Statistical Methods, 6th ed. Iowa State University Press: Ames.

Thomas JC, Katterman FR (1986). Cytokinin activity induced by thidiazuron. Plant Physiol. 81: 681-683.

Tunc, I., Berger, B.M., Erler, F. and Dagli, F. (2000). Ovicidal activity of essential oils from five plants against two stored-products insects, Journal of Stored Products Research, 36, 161;

Wua, S.C., Caob, Z.H., Lib, Z.G., Cheunga, K.C, and Wonga, M.H. (2004). Effects of biofertilizer containing $\mathrm{N}$-fixer, $\mathrm{P}$ and $\mathrm{K}$ solubilizers and $\mathrm{AM}$ fungi on maize growth: a greenhouse trial. Geoderma 125. p:155.166. 
تأثير التسميد الحيوى والكيماوى والرش بالTDZ على المواد الفعاله لنبات الينسون

\section{للسادة الاكاترة}

محمد خليل خليل' ، جمال السيد غزال'، عبير محمود'، داليا عبدالحليم سلامُّ

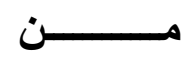

'فرع فسيولوجيا النبات،قسم النبات الزر اعىـ كلية الزر اعه، جامعة القاهرهـ شار ع الجامعهـ الجيزهـ جمهورية مصر العربيه

كأشبة النباتات الطبيه و المنتجات الطبيعيهـ الهيئه القوميه للرقابه و البحوث الدو ائيه ـــ الجيزهـ جمهورية مصر العربيه

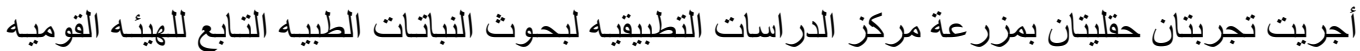

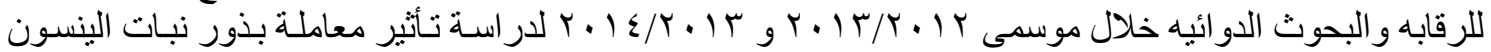

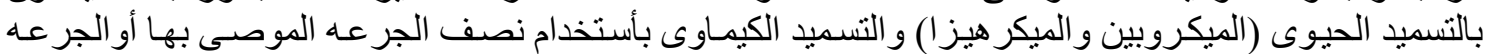

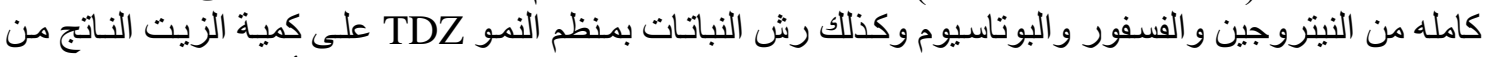

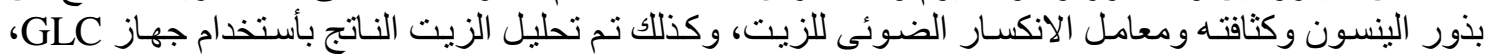

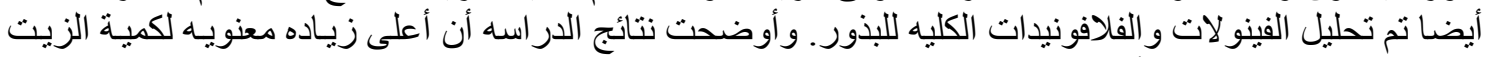

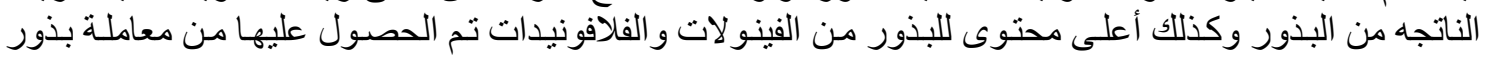

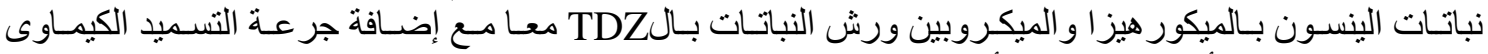

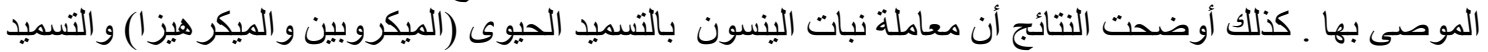

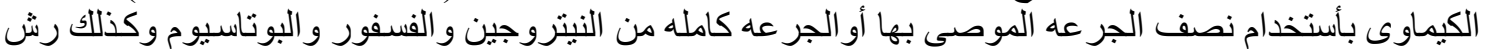

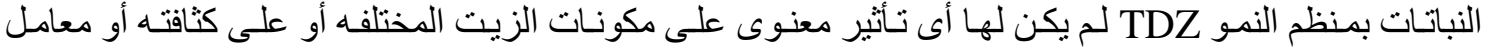

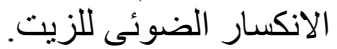

